\title{
From Defamation to Adoration: The Reception of Kraftwerk in the British Music Press, 1974-1981
}

\author{
"We are not artists, nor musicians. First \\ of all, we are workers." \\ (Ralf Hütter, Kraftwerk)
}

Uwe Schütte (Aston University)

Kraftwerk, it can be claimed, is the German pop music group that commands the greatest admiration on the British Isles. Their 2017 UK tour comprised twelve dates that sold out almost immediately. The press echo was overwhelmingly positive, for example The Independent heading their review of the Royal Albert Hall concert with the line: "Reconfiguring what a pop gig can be - and how it can look". ${ }^{1}$ Reviewer Shaun Curran opens his piece with affirming "the reverence with which groundbreaking German electronic group Kraftwerk are held today" in the UK, adding "Kraftwerk are arguably, perhaps even more than The Beatles, the most influential band of all time". ${ }^{2}$

Similarly, The Guardian review praised the pioneering role of Kraftwerk: "They were former avant-rockers from Düsseldorf whose evolving visions seeded modern music, from disco to hip-hop to techno. Anyone using a vocoder, or wearing a robot helmet or a mouse head, is their offspring."3 But reviewer Kitty Empire stresses another important aspect of the concert: "The sight and sound of Kraftwerk's multilingual, pan-European mindset is particularly bittersweet tonight, with Brexit talks now under way."4

Her remark reminded readers that Kraftwerk's summer dates coincided with the first anniversary of the Brexit referendum. The leading online music magazine The Quietus even ran a reflective piece entitled "Europe, Endless? On Watching Kraftwerk Live, A Year After Brexit” by the music journalist Luke Turner.

\footnotetext{
${ }^{1}$ Shaun Curran, "Kraftwerk 3-D at the Royal Albert Hall, London: Reconfiguring what a pop gig can be - and how it can look", in Independent, 23.6.2017.

2 Ibid.

${ }^{3}$ Kitty Empire, "Kraftwerk. Past masters of the future", in The Guardian, 25.6.2017.

4 Ibid.
} 
Bemoaning the outcome of the referendum, the article initially asks the question: "Do we Brits no longer deserve their European futurism?", while Turner, prompted by seeing the London concert, observes:

An idealised sense of the European is distilled in every vibration of every note and tonight that feels like another world. The culture they [Kraftwerk] came from has its flaws but seems to progress, evolve, recover, all those words of human and holistic positivity. Meanwhile, Britain scrabbles around in our sandpit, the castles of our national certainty crumbling, paper flags soggy in the summer rain. ${ }^{5}$

Quoting Kraftwerk, or rather: their European art music as an epitome of what Britain has lost culturally by severing its political bonds with the European Union, is apposite given that Kraftwerk, though initially stressing their German identity, soon evolved into an artistic project with a strong European identity: Russian supremacism, European pop art, German Fluxus, British performance art, Italian Futurism, French cycling culture, and many other cultural historical reference points served as inspirations for their pop-cultural Gesamtkunstwerk. ${ }^{6}$

How quickly Kraftwerk switched from foregrounding their Germanness to emphasizing exemplary Europeanness to sharply differentiate their image from those of Anglo-American pop music models, can be traced by an examination of their release history: While the lyrics on their 1974 breakthrough Autobahn were in German only, their next album, Radio-Aktivität (1975), featured bilingual lyrics. From its follow-up Trans Europa Express (1977) onwards, albums would be issued in parallel German- and English-language versions, while Techno Pop (1986) features multi-language lyrics in German, English, French and Spanish. Kraftwerk's last studio effort, Tour de France (2003), is sung almost entirely in French. ${ }^{7}$

Former band member Wolfgand Flür explained the intricate relation of Kraftwerk's Germanness with their European identity like this: „Wir haben bewusst angefangen mit der Musik der Alliierten zu brechen und eine europäische Identität zu

\footnotetext{
${ }^{5}$ Luke Turner, "Europe, Endless? On Watching Kraftwerk Live, A Year After Brexit", in The Quietus, 22.6.2017.

${ }^{6}$ On the question of the pop cultural Gesamtkunstwerk cf. Uwe Schütte (Ed.), Mensch-MaschinenMusik. Das Gesamtkunstwerk Kraftwerk (Düsseldorf: Leske, 2018).

${ }^{7}$ Kraftwerk were founded in 1970 and released three albums prior to Autobahn, which they disowned and relegated from their catalogue. I am uncritically following this decision here by treating Autobahn as their 'debut'.
} 
suchen. Wir wollten der angloamerikanischen Musikübermacht etwas entgegensetzen, das so erschreckend deutsch sein würde, dass man uns dafür geliebt hat. “8

In this article, I will focus on Kraftwerk's reception in the British music press (including sideglances to film and TV) during the decisive phase in the band's history, which is usually referred to as their "classical phase", that is to say the five concept albums from Autobahn (1974) to Computerwelt (1981), recorded with the stable line-up of founding members Ralf Hütter and Florian Schneider, aided by Karl Bartos and Wolfgang Flür. During this comparatively short period, ${ }^{9}$ the perception of the band in the UK reversed, going from xenophobic jibes, Germanophobic clichés, Teutonic stereotypes and other means of verbal defamation to pronounced admiration and adoration.

By tracing the UK reception of the Düsseldorf band, this article focuses on a pertinent example of Anglo-German cultural transfer in the areas of pop culture and the popular music press. I will demonstrate how Kraftwerk were recognised in the UK for changing the course of contemporary pop music and vastly influencing a wide range of musical genres. Their specific German "pop aesthetic with technological, economic and cultural roots distinctly different from those of the traditional AngloAmerican pop axis" $" 10$ became the foundation of the transnational sound of electronic pop music. $^{11}$

\section{Industrielle Volksmusik - Ethnic Music from Germany?}

The relase of Autobahn in November 1974 is now recognised as the beginnings of a distinct German strand of popular music, a merger of the avantgarde with the popular, and of the traditional with the futuristic. Kraftwerk's revolutionary vision was to employ (mostly) electronic sounds for a new type of pop music that aimed to develop a German alternative model to Anglo-American rock music centred around guitars. ${ }^{12}$

\footnotetext{
${ }^{8}$ Qtd. In Rüdiger Esch, Electri_City. Elektronische Musik aus Düsseldorf (Berlin: Suhrkamp, 2014), 10.

${ }^{9}$ Such an assessment is of course arbitrary; The Beatles also only took seven years to mutate from a Merseyside cover-band aping American music to the most innovative and revolutionary force in pop music during the golden age of pop culture.

${ }^{10}$ Alex Seago, "The 'Kraftwerk-Effekt': Transatlantic Circulation, Global Networks and Contemporary Pop Music", in Atlantic Studies 1:1 (2004): 85-106, here 90.

11 This transnational shift is explored in more detail in Uwe Schütte, Kraftwerk: Future Music from Germany (London: Penguin, 2020), 251-280.

12 Ralf Hütter polemically stated: 'The guitar is an instrument from medieval times. This entire business of rock music strikes us as entirely archaic. The music of a technicized world can only be made on instruments that have been devised by a technicized world." (EMI Press Release
} 
"Our music is electronic", Ralf Hütter explained, "but we like to think of it as ethnic music from the German industrial area - industrielle Volksmusik. It has to do with a fascination with what we see all around us, trying to incorporate the industrial environment into our music." 13

Former band member Wolfgang Flür's explanation provides an insight into what is meant by the ambiguous concept of industrielle Volksmusik which connects two seemingly antagonistic components: "We wanted to create a very Germanized style of modern pop music that drew on our romantic roots and folk traditions. [...] All this in strong interaction with technological themes, $[\ldots]$ modern instruments and our distinctive, self-conscious attitude. That was our creed. ${ }^{14}$ Flür is referring here to tracks such as "Morgenspaziergang" or "Franz Schubert", in which Kraftwerk recreate both Romantic melodies and the German music tradition by (mostly) electronic means.

But what is more important in this reference to the German tradition, is what Kraftwerk's industrielle Volksmusik renounces: it is not steeped in the American traditions of blues, jazz or rock, or the British pop music model. On the 'industrial' component of the term, Hütter gave the following explanation: "Es hat uns immer interessiert industrielle Musik zu machen. Fließband-Musik. Produktionsprozesse, die uns in der industriellen Welt umgeben."15 The type of music Hütter conceives here harks back conceptionally to the modernist notion that noise can be beautiful (as explored by avant-gardists from Luigi Russolo to John Cage), but, more importantly, it reflects - in form and style and sound - a modern civilization based on technology, manufacturing, electronic communication and the use of machines.

Tracks by Kraftwerk that embody this aesthetic include "Radioland", "Trans Europa Express", "Die Roboter", "Heimcomputer" or "Der Telefonanruf”, amongst many others. By making abstract, avant-garde ideas accessible to a wider listening public, the concept of industrielle Volksmusik gravitates strongly towards democratic ideas, aiming to unite the popular and artistic. In this sense, Kraftwerk's oeuvre has to be seen as an update of the musical project of The Beatles to "artify" and politicise pop

Computerwelt, 1981). I am grateful to the Klaus-Kuhnke-Archiv für populäre Musik in Bremen and Klaus Zäpke in Berlin for making available their holdings and expertise for this article. 13 Mark Dery, Interview with Ralf Hütter, in Keyboard Magazine 10 (1991).

${ }^{14}$ Qtd. in Rüdi Esch, Electri_City: The Düsseldorf School of Electronic Music (London: Omnibus Press, 2016), 116.

15 Willi Andresen, “Computer Liebe. Interview with Ralf Hütter”, in Tip 22 (1991), 202. 
music as a tool of social emancipation for the young generation. ${ }^{16}$ After all, the futurist thrust of Kraftwerk's music is strongly linked to utopian notions of technooptimism, while a declared aim of their artistic project was to use their industrielle Volksmusik as an artistic vehicle to express a new, untainted, positive German identity. Or as they put it succinctly in the Spanish section of the lyrics to "Electric Café": "Música electrónica / Arte política."

However, it is also important to understand that industrielle Volksmusik was an attempt to musically update the, as it were, academic school of electronic music centred around pioneers such as Karlheinz Stockhausen and Maurice Kagel or Pierre Schaeffer:

The first generation of electronic composers from France and Germany, they bring up their philosophy and their generation in their music. We're a new generation, after the war from the Bundesrepublik [...] and that's what shows in our attitude. We were raised on television and radio and media and the speed of city life, and we try to put this across in our music. ${ }^{17}$

The ambivalent nature of industrielle Volksmusik allows it to successfully merge and synthesize the two strands of music that traditionally, at least in Germany, have been separated out in ' $E$ ' and ' $U$ ', high-brow and entertainment, art and culture industry. Kraftwerk's pop-cultural Gesamtkunstwerk is neither and both at the same time.

\section{Subversive Over-Affirmation}

Developing a new, distinct German pop music that could work as an artistic vehicle for a new, positive German national identity posed two problems. Firstly, it required an answer to the difficult question: What does it mean to be German? Secondly, Kraftwerk felt it necessary to engage creatively with the many, readily available clichés of Germanness. "We have a Teutonic rhythm, really Germanic", ${ }^{18}$ Ralf Hütter proclaimed in 1981. But what is that supposed to mean, a 'Teutonic rhythm'? Evidently, such a boast before a French journalist is a calculated statement aiming to

\footnotetext{
16 The Beatles in turn served as a model to "artify" another German band, the Hamburg 'Diskursrocker' Tocotronic. Cf. Christoph Jürgensen, "PopKunst zu KunstPop: Strategien der populären Selbstverkunstung am Beispiel von Tocotronics Konzeptalbum Kapitulation", in KulturPoetik 16:1 (2016): 64-88.

17 Toby Goldstein, "Better Living through Chemistry", in New Musical Express, 24.12.1977.

18 Qtd. in Tim Barr, Kraftwerk: From Düsseldorf to the Future (with Love) (London: Ebury Press, 1998), 142.
} 
create a unique selling point for Kraftwerk's image by falling back on readily available stereotypes.

Paul Alessandrini, a journalist and close friend of the band, described their approach as follows: "They have always made use of stereotypes, it's like they say: 'We came from a country which evokes a certain type of imagery, a lot of clichés, so let's play this game, let's transform ourselves into these stereotypes." ${ }^{19}$ Such conduct, however, was not an unusual move as such for German bands; it evidences a pop-musical stratagem that, particularly in the later context of German punk music, ${ }^{20}$ became a vital means of differentiation from the Anglo-American punk rock model: 'subversive over-affirmation'.

At the beginning of their career, the founding members of Kraftwerk purposefully alluded to their Germanness, particularly when interviewed by Englishspeaking journalists. But they did not emphatically stress their German origins to express a sense of nationalist pride or the like. Rather, Hütter and Schneider aimed to highlight a void. Speaking in 1976, Hütter said: 'There's a whole generation in Germany, between the ages of 30 and 50, that has lost its own identity, and that never even had any. ${ }^{21} \mathrm{He}$ also explained:

There was really no German culture after the war. Everyone was rebuilding their homes and getting their little Volkswagen. In the clubs when we first started playing, you never heard a German record, you switched on the radio and all you heard was Anglo-American music, you went to the cinema and all the films were Italian and French. That's okay, but we needed our own cultural identity. ${ }^{22}$

To employ German lyrics on their game-changing song 'Autobahn' was a bold step. Kraftwerk made "a virtue out of their nationality rather than concealing it under an Anglo-American veneer"23 like the vast majority of their Krautrock contemporaries, who regularly opted for an English band name and simply aped Anglo-American pop music by singing in English.

\footnotetext{
${ }^{19}$ Qtd. in Pascal Bussy, Kraftwerk: Man, Machine, Music (London: SAF, 2001), 57.

${ }^{20} \mathrm{I}$ am referring to German punk bands like F.S.K., S.Y.P.H. or Fehlfarben, who for example wore suits and ties on stage or sang songs like "Ein Kind für Helmut" or "Zurück zum Beton" in oder to offend the conventional punks or the adherents of the ecological movement.

${ }^{21}$ Paul Alessandrini, Interview de Ralf Hütter \& Florian Schneider, in Rock \& Folk 11 (1976); English version at http://www.thing.de/delektro/www-eng/kw11-76.html (22.02.2020).

${ }^{22}$ Qtd. in Barr, Kraftwerk, 64.

${ }^{23}$ Barr, Kraftwerk, 8.
} 
Kraftwerk wanted to create a new, genuinely autonomous type of music anchored in their contemporary political, social, cultural and economic context surroundings: "We had this famous German movie director Rainer Werner Fassbinder and he did the movie to the Bundesrepublik. Joseph Beuys making the art, and we felt we should make a statement how this Bundesrepublik, this Deutschland would sound", ${ }^{24}$ Karl Bartos explained, while Ralf Hütter poignantly asked: "What is the sound of the German Bundesrepublik?",25

But rather than see themselves as speaking in the name of West Germany in its entirety, Hütter and Schneider strongly associated their vision of an authentic German pop music with their regional surroundings and traditions - "ethnic music from the Rhine-Ruhr area", ${ }^{26}$ as Florian Schneider put it. Ralf Hütter stated: "Countrymusik beispielsweise vermittelt einen Eindruck vom Leben in Texas. Diese Musik aber hat nichts mit uns in Düsseldorf zu tun. Wir haben unsere Musik stets als spezifisch industrielle Musik verstanden. Und daher auch als Form der Heimatmusik." 27

\section{Autobahn - Problematic Beginnings}

But how did this 'ethnic music' from Düsseldorf, Germany, travel interculturally to Britain? What is now acknowledged as the decisive paradigm shift in German popmusic, the release of Autobahn in November 1974, initially went largely unnoticed, both in the UK and Germany. Around the time of release, there was only one vaguely positive album review in the German music magazine Sounds and a short, indifferent review in the British New Musical Express. The German reviewer, Hans-Joachim Krüger, characterised the title track as "eine durch elektronische Hilfsmittel skurril vertonte Autofahrt”, and gives this verdict: “Insgesamt ist Kraftwerks ,Autobahn' ein abwechslungsreicher, vor allen Dingen amüsanter Trip, der, besonders unter Kopfhörern, seine Wirkung hinterläßt.“'28

Meanwhile, the anonymous British reviewer in the New Musical Express showed himself less impressed: He claims that the album "finds Kraftwerk dimly

\footnotetext{
${ }^{24}$ Oral statement by Bartos in the Swedish Kraftwerk TV documentary Pop i focus, dir. Malik Bendjelloul. SWE 2001.

${ }^{25}$ Qtd. in Stephen Dalton, „Album by Album: Kraftwerk“, in Uncut 10 (2009): 68-71, here 70.

${ }^{26}$ Qtd. in Alexander Simmeth, Krautrock transnational. Die Neuerfindung der Popmusik in der BRD, 1968-1978 (Bielefeld: Transcript, 2016), 259.

${ }^{27}$ Andresen, “Computer Liebe. Interview with Ralf Hütter", 202.

${ }^{28}$ Hans-Joachim Krüger, „Kraftwerk: Autobahn“, in Sounds 12 (1974).
} 
fumbling for approachability" and argues further that: "Hutter [sic!] and Schneider try for a Concept - a drive down the motorway - and convincingly blow the few avantgarde credentials fans of their earlier work mysteriously awarded them." The review closes with the damming assessment: "Simple minds only."29

Both Record Mirror and Melody Maker ran their very short reviews only three months later. While the former demonstrates a more sympathetic view of the album: "Strange little record this, lots of synthesisers and repetitive riffs that get to you after a couple of plays", ${ }^{30}$ the latter concludes its evaluation negatively with a disdaining "Miss." ${ }^{31}$ During this period, a three-minute radio edit of the 22-minute long album version of "Autobahn" had become a Top 40 hit in the US. The Melody Maker review comments on this surprise success thusly: "The traditional reserve of the English will make [the album's] task difficult over here, however, although it is one of the most original and inventive sounds to echo around a [Melody Maker] office.”32

While both reviews feature no German clichés, the music is described by the Melody Maker reviewer as follows: "Odd noises, from percussion and synthesiser drift out of the speakers without any comprehensible order while a few words are muttered from time to time in a strange tongue." 33 The first time stereotypes openly emerge is in the context of reporting on the Kraftwerk UK tour in autumn 1975. An extensive New Musical Express article on the concert at the Hammersmith Odeon by Jonathan Barnett, entitled "Learn to love your music machine", opens with this selfcritical observation:'

It's easy to label Kraftwerk with all the clichéd descriptions of the German race - polite, hardworking (too hardworking), but arrogant, cold, austere, and overdisciplined to the point of regimentation; but however accurate such a statement might be, it would fundamentally underestimate Kraftwerk's music, which often has a not unintentional melodic and rhythmic compulsiveness. ${ }^{34}$ Interestingly, the German stereotypes are here both cited and critiqued; similarly the reviewer also defends the minimalism of "Autobahn" from a seemingly all too evident accusation, namely that of "the absurd conception of a stern-faced Kraut

\footnotetext{
${ }^{29}$ NN, „Kraftwerk: Autobahn“, in New Musical Express, 15.2.1975.

${ }^{30}$ NN, „Kraftwerk: Autobahn“, in Record Mirror, 3.5.1975.

31 NN, „Kraftwerk: Autobahn“, in Melody Maker, 3.5.1975.

32 Ibid.

33 Ibid.

${ }^{34}$ Jonathan Barnett, "Learn to love your music machine”, in New Musical Express, 29.7.1975.
} 
monotonously intoning the German word for motorway as though it were some soulliberating Mantra."35

The important shift of Kraftwerk's image in the Anglophone world towards a decidedly clichéd perception was brought about by the notorious piece "Kraftwerkfeature", written by the American gonzo journalist Lester Bangs and first published in the Detroit-based magazine Creem in September 1975. "Where is rock going?", asks Bangs, only to provide the answer himself: "It's being taken over by the Germans and the machines." 36 Autobahn, to him, is "more than just a record, it is an indictment. An indictment of all those who would resist the bloodless iron will and order of the ineluctable dawn of the Machine Age". ${ }^{37}$ Equally, Bangs did not shy away from ad hominem attacks: Florian Schneider, he writes, looks "like he could build a computer or push a button and blow up half the world with the same amount of emotion". 38

However, Bang's interview-essay only reacts to Kraftwerk's careless toying with Germanic clichés when interviewed at the height of their US chart success by American journalists. Rather than critically responding, Hütter and Schneider ironically exaggerated and coldly satirized Anglo-American truisms about Germans by assuming the roles assigned to them: "We want the whole world to know our background. We cannot deny we are from Germany, because the German mentality, which is more advanced, will always be part of our behaviour."39

A statement like this clearly employs an ironic sense of subversive overaffirmation designed to project a unique image of the band within the context of American rock music, but it also proved to be a dangerous strategy indeed. When the piece appeared in print, it was emblazoned with an illustration showing a Nazi-style eagle holding a large swastika in its claws, which made it look like an official Nazi propaganda publication from the thirties. One particularly successful attempt by Bangs to associate Kraftwerk with Nazi imagery was his suggestion that electrodes should be implanted into the brains of their audience, allowing the band to communicate this way:

\footnotetext{
35 Ibid.

${ }^{36}$ Lester Bangs, "Kraftwerkfeature", in Psychotic Reactions and Carburettor Dung: The Work of a Legendary Critic: Rock'n'Roll as Literature and Literature as Rock'n'Roll (New York: Anchor Press, 1988), 154.

37 Ibid.

38 Ibid., 157.

39 Ibid., 158.
} 
'Yes,' enthused Ralf, 'this would be fantastic.'

The final solution to the music problem, I suggest.

'No, not the solution. The next step.'40

The British media immediately picked up on this. The headline in the New Musical Express reprint of the article blurted out: "Kraftwerk: the final solution to the Music Problem?"41 Encouraged by Creem's choice of illustration, the English version was accompanied by a photo of the band inserted into an image that supposedly showed the Party Convention Grounds in Nuremberg, insinuating once more that Kraftwerk were bona fide Nazis. The reprint features a kind of postscript missing in the American original, declaring: "Three LPs featuring Third Reich numbers (by various artistes - Hess, Goeobels [sic!], Goering [sic!], and Adolf - also featuring a 'scientific commentary' by 'Dr. Ritter') $)^{42}$ are currently 'selling well' in the Fatherland. - ED." 43

In its plain clumsiness and obvious absurdity, this unnecessary addendum provides a perfect example for the type of British humour that, although it may not intend to insult as it doesn't take itself seriously, clearly communicates an antiGerman message. "War das also britischer Humor", asks former band member Karl Bartos sarcastically in his autobiography, "Ob das englische Publikum die Botschaft des New Musical Express verstanden hatte oder nicht - es blieb zu Hause. Wir spielten vor leeren Sälen in Newcastle, Hampstead, Bournemouth, Bath, Cardiff, Birmingham und schließlich am 11. September in Liverpool.“44

After that disastrous tour, a pivotal event occurred in the UK reception of Kraftwerk: their first appearance ${ }^{45}$ on the BBC TV programme Tomorrow's World on 25 September 1975. This first British TV appearance, which lasted for little more than two minutes, is today considered a "seismic moment in the history of music" 46 and a "key event in the history of dance music". ${ }^{47}$ While Kraftwerk played "Autobahn", presenter Raymond Baxter explained that

\footnotetext{
40 Ibid., 159.

${ }^{41}$ New Musical Express, 6.9.1975.

${ }^{42}$ A reference to the 'race scientist' Dr Robert Ritter, a prominent figure in the racist prosecution of gypsies during the Third Reich.

${ }^{43}$ New Musical Express, 6.9.1975.

${ }^{44}$ Karl Bartos, Der Klang der Maschine (Köln: Bastei Lübbe, 2017), 170.

45 The band, or rather their robot doubles, would appear again on the programme in June 1991.

${ }^{46} \mathrm{Cf}$. Phil Hebblethwaite, How the BBC reported 11 seismic moments in the history of music, https://www.bbc.co.uk/music/articles/19ea91f9-83b5-4033-b64b-21af12678fcb (last accessed 1.5.2020).

${ }^{47}$ Andrew Harrison, Kraftwerk appear on Tomorrow's World: Number 1 in our series of the 50 key events in the history of dance music,
} 
Kraftwerk have a name for this: it's 'machine music'. The sounds are created in their laboratory in Dusseldorf, programmed and then recreated onstage with a minimum of fuss. Last year, they removed the last recognisable instrument, a violin, and built their synthetic drums. [...] Next year, Kraftwerk aim to eliminate the keyboards altogether, and build jackets with electronic lapels which can be played by touch. ${ }^{48}$

It was a considerable accolade to be featured in a popular science TV programme that introduced pioneering technology which would revolutionize everyday life, and it proved to be a perceptive choice by the programme producers. Whereas in the music press it had not been the case, in Kraftwerk's TV debut the joke was clearly on the British media since the band of course never seriously entertained the plan Baxter mentioned in his final remark. He had taken seriously one of the fake statements they made to journalist to further their image of being technologically innovative. Although it would have been easy to link such bragging with stereotypes of superior German engineering capabilities or such like, the TV show avoided clichés. Nevertheless, it failed to influence the parochial attitude of the British music press, as attested by the latter's reaction to Radio-Aktivität.

\section{Radio-Aktivität - Updating Stockhausen}

The Creem/New Musical Express-disaster evidently taught Hütter and Schneider a valuable lesson given that they were more careful in their use Germanic of stereotypes during interviews from that point on, but Kraftwerk interestingly continued their ambivalent play with Teutonic iconography. The follow-up to Autobahn was released in October 1975 and had an ambivalent title: Radio-Aktivität. This, Kraftwerk's first true concept album, reflected contemporary debates about nuclear energy, but at the same time amounted to an experimental radio play about the fascination that radio broadcasting exerted on Hütter and Schneider as children and young adults. As such, it constitutes a remarkable homage to the great avantgarde tradition in German music, particularly to Karlheinz Stockhausen and his pioneering experiments at the WDR Studio für elektronische Musik in Cologne.

https://www.theguardian.com/music/2011/jun/15/kraftwerk-tomorrows-world (last accessed 1.5.2020).

${ }^{48}$ Raymond Baxter on Tomorrow's World 1975,

https://www.youtube.com/watch?v=sl46bxHuyR8 (last accessed 1 May 2020) 
Associated with this artistic genealogy, industrielle Volksmusik took on a very different quality than that of pop music in the Anglo-American tradition, namely the (perceived) 'coldness' of electronic music. This was often said of Kraftwerk's music around the time of Autobahn and Radio-Aktivität. For instance, in "Mechanical Kraftwerk", a review of a live show in Melody Maker in May 1975, Todd Tolces remarks that the concert he witnessed "would've been a field day for all the critics who've ever said how unemotional and cold electronic music really is. Because that's what this music was: cold music." 49 Equally, the static stage performance and uniform look of the Kraftwerk band members, along with the stage equipment consisting of "a variety of purely electronic instruments", struck the journalist as devoid of emotion and hence as "cold, even to the point of being perverse". 50

This insistent focus on the aspect of coolness points to a marked opposition: "Die Pop-Musik wird [...] von Wärmezuständen bestimmt", writes Marcus S. Kleiner with Radio-Aktivität in mind, adding:

Das Kalt-Werden der (Pop-)Musik in der Spielart von Kraftwerk steht in dieser Hinsicht in Opposition zur dominanten anglo-amerikanischen PopMusik der 1950er bis 1970er Jahre, die sich als ästhetische, semantische und lebensweltliche Geschichte der Hitze und Erhitzung und als eine Geschichte aufregender und ausschweifender Sinnlichkeit beschreiben lässt. ${ }^{51}$

That is to say, the coolness of Kraftwerk's electronic pop music is due to its deviation from the established, dominant Anglo-American patterns of pop music; in addition to shifting to electronic instrumentation and sound, it replaces the personality cult of pop/rock musicians with an aesthetic strategy of depersonalisation and substitutes a new coolness for the release of affect and erotic emotions in the audience that accompanied the stage performances of such early superstars as Elvis or The Beatles. A coolness, that is German in origin - and though strongly articulated by the reviewer, it is not identified as German by Tolces.

Keith Ging opens his Melody Maker live review, published in September 1975 and entitled "Kraftwerk - men or machines?", with the following question:

\footnotetext{
49 Todd Tolces, "Mechanical Kraftwerk", in Melody Maker, 24.5.1975.

50 Ibid.

51 Marcus S. Kleiner, „Cool Germany. Elektronische Entsinnlichung in Kraftwerks Radio-Aktivität“, in Schütte (Ed.), Mensch-Maschinen-Musik, 50-63, here 61.
} 
What possible new realms of musical development will our machine age bring next? Surely an emotional and human involvement with the art will always be present. Or, of course, it will cease to be art. But after watching the enormously popular German machine operators known as Kraftwerk [...] this reviewer is not so sure. [...] A fully automated society on earth is quite a dream - but for God's sake keep the robots out of music. ${ }^{52}$

Again, it appears remarkable that Kraftwerk's innovative conceptual approach to pop music, "the lastest product of Germany's curious and unqiue national school of mechanistic electronic music", 53 is not necessarily linked to stereotypes in these two concert reviews, while the album review of the new album Radio-Aktivität in the same magazine operates with open anti-German bias:

This is technology for the children of the German economic miracle, philistine and uncreative, but providing a direct line into the Germanic psyche. So, naturally, it is kitsch, and what more natural that it should finish up with a kitsch tune, "Ohm Sweet Ohm" (ouch!) that one can imagine being played on little piano-top synthesizers in beer cellars all over the Fatherland as the patrons go home to their cosy little beds. ${ }^{54}$

The intellectual form anti-Germanism takes in this unfavourable review is striking, in particular since it condemns as kitsch what is probably, in terms of stylistic variety, Kraftwerk's most sophisticated album. Both the album's ambivalent word play "radioactivity" versus "radio's activity" (of broadcasting music) and its nature as an avantgarde radio play were apparently lost on the reviewer. David Stubbs would later, more accurately, describe Radio-Aktivität as "a milestone in electronic music, one that marks a precise and signal midpoint between Stockhausen and Depeche Mode". 55

\section{Trans Europa Express - Europe Endless (With a Detour via Chris Petit)}

It was only with Trans Europa Express, released in March 1977, that Kraftwerk's insistence on decidedly Germanic subjects disappeared. The theme of driving on the German Autobahn was substituted by the notion of luxurious travel on the Trans

\footnotetext{
52 Keith Ging, “Kraftwerk - men or machines?”, in Melody Maker, 13.9.1975.

53 B.H., „Kraftwerk“, in: Melody Maker, 7.6.1975.

${ }^{54}$ K.D. [Karl Dallas], “Kraftwerk: Radio-Activity”, in Melody Maker, 20.12.1975.

55 David Stubbs, Future Days: Krautrock and the Building of Modern German (London: Faber \& Faber, 2014), p. 181.
} 
Europ railway network, implying the criss-crossing of different cultures and languages. The transnational TEE network was in operation from the late 1950s up until the early 1990s. At its height in the mid-1970s, it connected 130 cities across Western Europe with regular high-speed services every two hours. The TEE system represented a modern, if expensive, lifestyle as the services only offered first-class fares.

Hütter and Schneider, whose Kling Klang studio was located near the Düsseldorf main railway station, often took the TEE to Paris to meet their French record company representative Maxime Schmitt or the journalist Paul Alessandrini, both of whom were close friends. Alessandrini claims that he inspired Trans Europa Express: while dining with the band in Le Train Bleu, a magnificently stylish restaurant located in the Gare de Lyon railway station in Paris, he told Hütter and Schneider: "With the kind of music you do, which is kind of like an electronic blues, railway stations and trains are very important in your universe, you should do a song about the Trans-Europe Express." 56

Indeed, the theme of trans-European train travel provided a perfect metaphor for Kraftwerk's aesthetic focus on technology and progress. Furthermore, it perfectly fulfilled the band's idea of treating technical objects as potential music-makers: if you pay attention to the noises your railcar makes, Hütter explained, "you'll realize that it is a musical instrument." 57 Trans Europa Express opens with "Europa Endlos", a track just short ten-minutes, singing the praises of a continent without borders. The song title was originally intended to serve as the album title, which highlights the importance Kraftwerk assigned to the notion of a borderless, unified, and hence "endless" Europe.

With its elegant electronic choirs and forward-pushing rhythm, the music creates the image of a never-ending journey across a beautiful continent, as expressed in the repeated mantra of "Europa endlos". This idealized journey is structured with the various sights a train passenger would see while looking out of a carriage window: "Parks, Paläste und Hotels / Europa endlos / Flüsse, Berge, Wälder / Wirklichkeit und Postkarten-Bilder". The musical train ride creates a continent in which the various

\footnotetext{
${ }^{56}$ Qtd. in Bussy, Kraftwerk, 90.

${ }^{57}$ Paul Alessandrini, „Haute tension: Kraftwerk“, in Rock \& Folk 11 (1976).
} 
regions and nations seem to have merged into one long row of nostalgic impressions, full of "Eleganz und Dekadenz".

The album review published on 28.5.1977 in the New Musical Express by Angus MacKinnon is devoid of any positive or negative allusion to Germanness - but it also fails to address the European theme in any way. It merely aims to balance what the reviewer perceives as the musical strengths and weaknesses of the album. Similarly, an extensive piece in the same paper by Toby Goldstein, which appeared on Christmas Eve 1977, refrains from any German stereotyping yet equally refuses to discuss the very theme of the concept album. The idea of Europe, it appears, seemed not worth any comment for English journalists at the time, a mere four years after the United Kingdom had joined the European Union in January 1973.

Goldstein's article, however, contains a prototypical statement as regards the mythology that Kraftwerk deliberately constructed around their image ${ }^{58}$ that describes their interesting transmedial career: "We are the children of Wern[h]er von Braun and Fritz Lang. We start from the "20s and jump into the " $80 \mathrm{~s}$ ". ${ }^{59}$ The primary intention of this assertion is obvious: Kraftwerk style themselves as a kind of cultural historical 'bridge-builders' from the Weimar Republic past to the immediate future of the Federal Republic.

Hütter explained the retro-futurist conundrum that Kraftwerk faced in the late 1970s as follows: "It sounds strange but to be able to continue into the future we had to take a step back forty years." 60 The reference to Fritz Lang seems self-explanatory given Kraftwerk's strong affiliation with Expressionist cinema. ${ }^{61}$ However, it is problematic to also include Braun. ${ }^{62}$ While his scientific achievements as an aerospace engineer and his visionary ideas regarding space travel (including the idea of a space laboratory orbiting the earth) make him suitable as a reference point for Kraftwerk's futuristic styling, Braun's personal and political life are of course

${ }^{58}$ Cf. Dirk Matejovski (Ed.), Kraftwerk: Die Mythenmaschine (Düsseldorf: DUP, 2016).

59 Toby Goldstein, "Better Living Though Chemistry", New Musical Express, 24.12.1977. The reference to Braun was picked up again by Jan Libenga, "De Kinderen van Werner von Braun", in Oor 10 (1978) 1, 47-48.

${ }^{60}$ Qtd. in Tim Barr, Kraftwerk. From Düsseldorf to the Future (with Love) (London: Ebury Press, 1998), 74.

61 The black-and-white video to „Trans Europa Express” is a clear reference to Weimar cinema and included various sequences that openly allude to Lang's Metropolis.

62 On their next album Mensch-Maschine Kraftwerk would pay homage to both men on the two instrumentals "Metropolis" and "Spacelab" respectively. 
strongly tainted by his association with the Nazi regime, and in particular by his work on developing the V-2 "vengeance weapon" that destroyed parts of London in World War 2.

Associating themselves with Braun could be seen as a manifestation of Kraftwerk's practice of embracing ambivalent aspects of German history. Whereas Lang was a émigré who left Germany to save his life, Braun was an opportunist and a morally tainted Nazi collaborator. It may well be that the choice of Braun was naïve at best. Hütter may have wanted to pair the pioneering film director with the pioneering engineer so as to conjure up the very balance of art and science that Kraftwerk considered as conceptually important for their work.

In any case, the above-mentioned genealogic statement appears prominently in the initial sequences of Chris Petit's debut film Radio On, a road movie released in 1979 that can be described as a cinematic homage to Kraftwerk, whose RadioAktivität features prominently in the soundtrack. However, there is also an intradiegetic reference since the protagonist, the DJ Robert, inserts cassettes of three Kraftwerk albums into his car radio while driving from West London to Bristol, where his brother had committed suicide. ${ }^{63}$ Hütter's statement about Lang and Braun appears at the 3:04-minute mark, anonymously, as a handwritten note ${ }^{64}$ on the wall on which the camera lingers for more than 20 seconds to allow the viewer time to read it. It has variously been assumed that Ralf Hütter himself wrote the note, ${ }^{65}$ but the director in fact wrote it.

"It is not too much of a stretch to connect Hütter's citation of von Braun, with its implicit reference to the continuation of German wartime technology into Cold War capitalist production, with Kraftwerk's earlier fascination with the autobahn", 66

${ }^{6}$ Cf. Matthew Pink, „Electronic Realities and Identity Fugue in Chris Petit's Radio On (1979)”, in: The Soundtrack 2:2 (2009): 143-152. "The cyclical, repetitive patterns of the Kraftwerk compositions are an excellent means to augment the monotonous rhythm of the film and acclimatize the spectator", Pink states, "With Kraftwerk, human sounds and musical sounds are deliberately designed to be conflated with the mechanical. They communicate with the brain via the theta brain waves - waves of greater amplitude but lower frequency that are induced by repetitive driving processes and coaxed by the electronic music." (147f)

${ }^{64}$ Cf. "We are the children of Fritz Lang and Werner von Braun. We are the link between the '20s and the '80s. All change in society passes through a sympathetic collaboration with tape recorders, synthesisers and telephones. Our reality is an electronic reality." (Radio On, UK 1979. dir. Chris Petit)

${ }^{65}$ Cf. for example David Cunningham, "Kraftwerk and the Image of the Modern", in Sean Albiez und David Pattie (Eds.), Kraftwerk. Music Non-Stop (New York: Continuum, 2011), 44-62, here 55. 66 Ibid. 
Cunningham states, taking Hütter at his word. However, the re-occurrence of the Braun/Lang reference is more indicative of the British perspective on Kraftwerk. What was of relevance from a British perspective was not so much the question of a continuation of fascist heritage into the Federal Republic, but the revitalisation of the liberal and experimental Weimar culture in the culture of the 1970s and 1980s, which chimed with British culture at the time. ${ }^{67}$

Furthermore, Kraftwerk were the subject of a mock film script by Petit entitled Am Diskö mit Kraftwerk. The Kraftwerk Movie that appeared in November 1978 in Melody Maker. The screenplay represents a highly unusual homage to Kraftwerk as well as an outlandish contribution to a music magazine. Hütter and Schneider feature in the script under collective shorthand symbol "K.", mostly in conversation with an anonymous persona called "C." There is no action or plot as such, only changing sequences of scenes and locations in Düsseldorf, plus captions and short stage directions, which create an overall surreal atmosphere. In one scene, set in a café, K. are eating cake while this dialogue ensues:

C. You call yourselves the children of Wern[h]er von Braun ...

$\mathrm{K}$. We see ourselves less as musicians than as scientists working in a sound laboratory.

C. ... And of Fritz Lang.

$\mathrm{K}$. We have always thought of our music being like a movie ...

K. ... Soundtracks.

K. Movie Soundtracks ${ }^{68}$

The script ends with these directions:

EXTERIOR. The Mercedes glides through the dark and deserted streets of Düsseldorf.

CAPTION. We are the link between the Twenties and the Eighties. All change in society passes through a sympathetic collaboration with tape-recorders,

\footnotetext{
${ }^{67}$ As attested by the fascination that Cabaret, the 1972 film adaptation of Christopher Isherwood's 1939 novel Goodbye to Berlin starring Liza Minelli, exerted on Anglophone artists and, in particular, as regards music, on David Bowie, Ian Curtis (of Joy Division), Lou Reed or, more recently, The Dresden Dolls, all of whom were influenced by the film's clichés of decadence and debauchery.

${ }^{68}$ Chris Petit, „Am Diskö mit Kraftwerk. The Kraftwerk Movie“, in Schütte (ed), MenschMaschinen-Musik. Das Gesamtkunstwerk Kraftwerk. 116-123. 118.
} 
polaroids, synthesizers, (INSERT) and telephones. Our reality is an electronic reality. ${ }^{69}$

Chris Petit's pairing of mock screenplay and actual film is a highly artistic appreciation of Kraftwerk's innovative approach to making pop music. Their approach stimulated Petit first to write a literary script, and then to make an unusual film that was later described by the writer Iain Sinclair as "an autobahn in disguise" and "a cultural landmark announcing the coming of Thatcher's children and the slow death of art cinema" ${ }^{70}$ Similarly, publishing the cod screenplay in a music magazine attests to the editorial freedoms that were seemingly available at the time. Devoting several pages of the first November edition of 1978 to Petit's Kraftwerk tribute also indicates an appreciation of the band by the editorial staff that counters the various times they were mocked and vilified for their nationality.

Returning to Goldstein's article again, it must be noted that the example set by the jingoistic editorial addition to reprint of Bangs's article in the New Musical Express gained traction in the magazine. While Goldstein steered clear of German stereotypes in his article, a photo of Hütter and Schneider at the end of his article was captioned with the ironic words: "Drs Ralph [sic!] Hutter [sic!] and Florian Schneider are universally reckoned to be amongst the world's foremost cyberneticists. Now you can benefit from their discoveries IN YOUR LIVING ROOM!!!"71

While the humour here is more of the admiring kind, alluding to clichés about 'mad German scientists', it is curious that the same photo reappeared in the magazine on 10.6.1978 when Kraftwerk won the accolade of single of the week for "The Robots", this time under the headline "Don't laff, earthling, vee haff joost made ze zingle off ze veek..." and captioned with: "Ralf and Florian celebrate another stunning German victory."72 This, in all likelihood, is a reference to the German victory in the friendly match against England in February 1978, which ended 2:1, and calls to mind the trope of football matches between Germany and England as a continuation of World War II. As this example shows, there was still a way to go until

\footnotetext{
${ }^{69}$ Ibid., 123.

70 Iain Sinclair, Ghost Milk: Recent Adventures Among the Future Ruins of London on the Eve of The Olympics (London: Faber \& Faber, 2012), 56.

${ }^{71}$ Goldstein, "Better Living Through Chemistry", New Musical Express, 24.12.1977.

72 NN, no title, New Musical Express, 10.6.1978.
} 
stereotypes and clichés were to vanish from the British music press's treatment of Kraftwerk.

\section{Die Mensch-Maschine - Music Journalism as ,Higher Education“}

A critical turning point in the perception of Kraftwerk's image in the UK was David Bowie's appreciation of the Düsseldorf group. He told Playboy magazine in 1976: "My favourite group is a German band called Kraftwerk - it plays noise music to 'increase productivity'. I like the idea, if you have to play music." ${ }^{, 73}$ In the introduction to his remarkable review of Mensch-Maschine, the music critic Andy Gill comments on the "chic appeal of David Bowie's favour" because it meant "a lot of folk [...] do not know why they like Kraftwerk, but are sure there must be something in them because David likes them". ${ }^{74}$

The review, entitled "Mind Machine Music", marks a turning point from the cautious, insecure approach to Kraftwerk's innovative music, in which British journalists obviously resorted to clichés since they lacked the capacity to appreciate their albums critically. Gill, however, offers a perceptive analysis and his assessments stand the test of time. His article is pop-music journalism at its best, framing and evaluating the album in a wider cultural and political context.

Gill's article mentions Joachim Fest's controversial Hitler biography, the suicide of Viennese "actionist" Rudolf Schwarzkogler, the hysteria among the public and politicians in connection with the left-wing terrorism of the Red Army Faction, as wells as brief references to EL Lissitzky, Le Corbusier, Fritz Lang, and Immanuel Kant. Gill's ruminations also betray evident familiarity with the Frankfurt School, and knowledge of the debate on the controversial Notstandsgesetze in West Germany.

"Mind Machine Music" stands as a fine example the educational role played by both pop song lyrics and music journalism in 1970s Britain in that it provides 'higher education' for a working-class audience or readership. Mark Fisher pointed out that in late 1970s Britain,

in this slough of despond, you could find working class kids who wrote songs steeped in Dostoyevsky, Conrad, Kafka, Burroughs, Ballard, kids who, without even thinking about it, were rigorous modernists who would have

\footnotetext{
${ }^{73}$ Cameron Crowe, "David Bowie. An outrageous conversation with the actor, rock singer and sexual switch-hitter", in Playboy 9 (1976).

${ }^{74}$ Andy Gill, "Mind Machine Music", in New Musical Express, 29.4.1978.
} 
disdained repeating themselves, never mind disinterring and aping what had been done 20, 30 years ago. ${ }^{75}$

In this article, Gill not only give a sophisticated answer to the question in the subtitle of his piece, "Who are These Men And Why Are They Wearing Red But Looking Right?", he also highlights the two competing thematic strands of the album, namely science and art, and proposes that "Kraftwerk manage to convey the melange" of these two strands "by musical means alone: the sparsity of the lyrics leaves the emphasis squarely on those robot rhythms, chilling tones and exquisite melodies". ${ }^{76}$ The review ends with a bold summary statement that adequately pinpoints today's assessment of the album: "The Man-Machine", Gill proclaims, "stands as one of the pinnacles of 70s rock music and one which [...] I doubt Kraftwerk will ever surpass." 77

The review by Karl Dallas, entitled "Inhuman Kraftwerk", which appeared on 6.5.1978 in the Melody Maker, equally praises Mensch-Maschine, albeit not as emphatically as Gill, with the words "this is really a rather good album". ${ }^{78}$ Dallas was particularly impressed by the fact that "their music is hard-edged, mechanised, to the ultimate, dehumanised, even inhuman". ${ }^{79}$ By thus avoiding German stereotypes, Dallas differentiates and distances himself from a report in the same magazine by Allan Jones on the Paris press launch of Kraftwerk's album, which appeared a fortnight earlier.

Under the title "Many hands make Kraftwerk", Jones assembles just about every xenophobic prejudice and jingoist stereotype current in British (popular) culture at the time. Notably, the thrust of his piece, reflecting the Parisian setting of the press event, is directed more at European culture in general than being an attack on the nationality of Kraftwerk. Jones describes them mockingly as "our favourite Germans" before embarking on sweeping insults of "Belgian hacks", "Continental Johnnies" and various aspects of French culture. For instance, Jones reports of "suffering from an

\footnotetext{
75 Mark Fisher Ghost of My Life. Writings on Depression, Hauntology and Lost Futures (London: Zero Books, 2013), 54.

76 Gill, "Mind Machine Music", in New Musical Express, 29.4.1978.

77 Ibid.

${ }^{78}$ Karl Dallas, „Inhuman Kraftwerk“, in Melody Maker, 6.5.1978.

${ }^{79}$ Ibid.
} 
acute attack of xenophobia" because the British press party was "persuaded to share a lift with giggling foreigners". ${ }^{80}$

Though sprinkled with a hint of irony, Jones' report paints a picture of British supremacy when abroad, explaining for example that "our hosts [...] barged into us, babbling incoherently in that curious manner peculiar to the French when they are either drunk or excited. Anglo-French relations are, we might say, critically tested in the circumstances; but we remain successfully aloof and naturally superior". ${ }^{81}$ The music of Mensch-Maschine is described with Nazi references such as "the soundtrack for an afternoon tea break at Krupp's. [...] Two sides of this and we are almost off to invade Poland. Czechoslovakia, here we come!" 82 The arrival of the band members to the party triggers a barrage of the cheapest German stereotypes:

The Huns clock in about two hours after the vodka trickles out. They're dressed almost identical [...] Their hair - I almost typed 'herr' - is shorn in the style of the military and slicked back. They smile as often as it snows in Abu Dhabi. They troop in, dancing a precise two step: I look for the clockwork keys between their shoulder blades. We are introduced.

[...] Florian reminds me of Kenneth Mars, the Nazi author of Springtime For Hitler [...] I say hello. He nods his head sharply. He doesn't click his heels. ${ }^{83}$ Jones's piece stands out not just through its outspoken xenophobia but even more so by conjuring up Nazi associations at a time when stereotyping of Kraftwerk had almost disappeared in the British media. Clearer than in other cases, this piece of journalism suggests that British insecurity abroad leads to such cliché mongering, i.e. that the author wass unfamiliar with and intimidated by French culture.

\section{Computerwelt - Future Music from Germany}

Computerwelt arrived in May 1981 and represents Kraftwerk's most futuristic work. It denoted a turning point in the band's public image as Ralf Hütter now openly discussed their politics, revealing a pronounced leftist position, inspired partly by Critical Theory and partly by a Foucauldian critique of institutional power structures. "Is your music the music of a controlled society?" Neil Rowland asked with a

\footnotetext{
${ }^{80}$ Allan Jones, “Many hands make Kraftwerk", in Melody Maker, 22.4.1978.

${ }^{81}$ Ibid.

82 Ibid.

83 Ibid.
} 
Deleuzian nod in his interview published in 4.7.1981 in the Melody Maker. Hütter replied:

By making transparent certain structures and bringing them to the forefront that is a technique of provocation. First you have to acknowledge where you stand and what is happening before you can change it. I think we make things transparent, and with this transparency, reactionary structures must fall. ${ }^{84}$ While Mensch-Maschine only hinted at the possible threat of a resurgence of totalitarianism in the satisfied German middle-class society during the social democratic era under chancellors Brandt and Schmidt, Computer Welt was an openly political record. It was also breathtakingly prophetic, foretelling computer-based government surveillance of the population, the rise of video game culture and online dating, the victory march of hand-held electronic devices as well as personal desktop computers in every home, plus the advent of globalised electronic capitalism and the increasing digitalisation of public administration. This seems even more remarkable, given that the album was recorded on analogue equipment and arrived in record stores before IBM had released its first Personal Computer.

Computerwelt pioneered the electronic sound that now largely defines the notion of popular music globally, from club music to rap and R'n'B etc. It had taken Kraftwerk three years to work on the album, the longest time ever between the release of a new studio work and its predecessor, but the result was accordingly sophisticated. As Andy Gill put it in his review for the New Musical Express from 16.5.1981:

Kraftwerk's subtlety is often overlooked: they seem so straightforward, so logical, it's easy to miss the tonal subtlety of their compositions, the pure, glacial perfection of their chosen synth-tones, the millisecond precision of their delay times, and a thousand other seemingly insignificant little elements that combine to evoke their peculiar atmospheres. ${ }^{85}$

A case in point for the sonic innovation on the album is a piece as otherworldly and radically new as "Nummern". The track may be cited as the prime example of Kraftwerk's approach of fusing minimalism with functionality. The track represents a radical exercise in reduction. An almost brutal piece of music with its relentless drum pattern, it strictly adheres to the Bauhaus credo that function dictates form, the 'lyrics'

\footnotetext{
${ }^{84}$ Neil Rowland, Electronic Zeitgeist, in Melody Maker, 4.7.1981.

${ }^{85}$ Andy Gill, „Kraftwerk: Computer World“, in New Musical Express, 16.5.1981
} 
offer only what is promised by the title, namely the repeated recital of the numbers from one to eight. In its radical reduction, the mesmerizing track encapsulates the guiding aesthetic ideas that govern Kraftwerk's man-machine music into a prototechno track.

Reviews of Computerwelt featured no more clichés but instead provided precise descriptions of the music. The fact that Kraftwerk are from Germany is now a piece of factual information, no longer a cause for Teutonic taunts. For example, Ian Pye's review in the Melody Maker from May 1981 states: "Kraftwerk can be cold but elegant, stark but poignant. Their medium is ruthlessly mechanical; their spirit is warm and glowing. They make the modern world seem empty yet beautiful." 86 Qualities that would previously have triggered Germanic stereotypes are now balanced and used as points of praise.

From Computerwelt forward, Kraftwerk were finally acknowledged as great German modernists and innovators. This standing was reflected in the chart success the band enjoyed in the UK: "The Model" reached number one on the UK singles chart in February 1982 and spent a total of 21 weeks in the Top 75. This hit single led to the band's second important appearance on UK TV, on Top of the Pops on 4 February 1982.

This chart success was a true surprise as the song had been originally included on the Mensch-Maschine album three year earlier. It served as the B-side to the UK “Computer Love" single lifted from Computerwelt and released in July 1981. However, when it turned out that "The Model" was more popular with radio DJs than the A-side, the song was re-issued in December 1981 as the A-side, which allowed it to reach number one.

This was the first time that Kraftwerk had gained that coveted position in any country, ${ }^{87}$ as well as the first time that any German band or artist had manged to achieve this accolade in the UK. It can therefore be argued that Computerwelt concluded the process of full acceptance of Kraftwerk's industrielle Volksmusik in the UK. However, whereas the album constitutes an artistic apex in their release history, "The Model" chart success was also a commercial sell-out since the single features a rather bland melody and hardly ranks among Kraftwerk's best work musically.

\footnotetext{
${ }^{86}$ Ian Pye, „Kraftwerk: Computer World”, in Melody Maker, 9.5.1981.

87 They didn't reach number one in Germany until 2003, with Tour de France Soundtracks, in the German album charts.
} 
The song's lyrical themes of commerce, sex, drinking and dancing at a nightclub are decidedly at odds with Kraftwerk's futurist and technological aesthetics yet, for this very reason, "The Model" became the blueprint for the emerging synth pop movement. Kraftwerk handed over the baton, as it were, to the many musicians who then began to merge German electronic cool with a British sensibility for pop music, bands such as Visage, New Order, Depeche Mode, The Human League and Duran Duran, as well as solo artists such as David Bowie and Gary Numan. Their synth pop forged a transnational sound that defined European pop music throughout the 1980s, and continues to influence it up to the present. 